NEGOTIATING THE CONSTITUTION 



\title{
NEGOTIATING THE
}

\section{COnstitution}

\section{The Earliest Debates}

\author{
over Original Intent
}

Joseph M. Lynch

Cornell University Press Ithaca and London 


\section{Copyright (C) 1999 by Cornell University}

All rights reserved. Except for brief quotations in a review, this book, or parts thereof, must not be reproduced in any form without permission in writing from the publisher. For information, address Cornell University Press, Sage House, 512 East State Street, Ithaca, New York 14850.

First published 1999 by Cornell University Press.

First printing, Cornell Paperbacks, 2005.

Printed in the United States of America.

\section{Library of Congress Cataloging-in-Publication Data}

Lynch, Joseph M. (Joseph Martin), 1924-

Negotiating the Constitution : the earliest debates over original intent / Joseph M. Lynch.

p. $\mathrm{cm}$.

Includes index.

ISBN-13: 978-0-8014-3558-4 (cloth: alk.paper)

ISBN-10: 0-8014-3558-7 (cloth alk. paper)

ISBN-13: 978-0-8014-7271-8 (pbk.: alk.paper)

ISBN-10: 0-8014-7271-7 (paper : alk. paper)

1. United States. Constitutional convention (1787)

2. Constitutional history - United States. 1. Title.

KF4510.L96 1999

$342.73^{\prime} 029-\mathrm{dc} 21$

$98-43447$

Cornell University Press strives to use environmentally responsible suppliers and materials to the fullest extent possible in the publishing of its books. Such materials include vegetable-based, low-VOC inks and acidfree papers that are recycled, totally chlorine-free, or partly composed of nonwood fibers.

Cloth printing $\quad 10987654321$

Paperback printing $\quad 1098765432$ 


\section{To Irene}


The threatening contest, in the Convention of 1787 , did not, as you sup1 posed, turn on the degree of power to be granted to the Federal Govt: but on the rule by which the States should be represented and vote in the Govt: . . . The contests \& compromises, turning on the grants of power, tho' very important in some instances, were Knots of a less "Gordian" character.

James Madison to Martin Van Buren, May 13, 1828 